\title{
Additional new organic-walled dinoflagellate cysts from two onshore UK Chalk boreholes
}

\author{
Martin A. Pearce \\ Evolution Applied Limited, 50 Mitchell Way, Upper Rissington, Cheltenham, Gloucestershire, GL54 2PL, UK \\ Correspondence: Martin A. Pearce (info@evolutionapplied.com) \\ Published: 5 January 2018
}

\begin{abstract}
Beautifully preserved dinoflagellate cysts continue to be discovered in UK Cretaceous chalks and provide important new biostratigraphic information. Five new species - Conosphaeridium norfolkense sp. nov., Glaphyrocysta coniacia sp. nov., Impletosphaeridium banterwickense sp. nov., Sentusidinium devonense sp. nov., Sentusidinium spinosum sp. nov. and the new subspecies Spiniferites ramosus subsp. ginakrogiae subsp. nov. are described from Upper Cretaceous strata of the British Geological Survey (BGS) Banterwick Barn and Trunch boreholes (onshore UK). An emended diagnosis for Odontochitina diducta Pearce is also provided to broaden the morphological variability in the type material.
\end{abstract}

\section{Introduction}

Cretaceous chalks from onshore UK boreholes have recently yielded beautifully preserved dinoflagellate cysts (Prince et al., 1999, 2008; Pearce et al., 2003, 2011; Pearce, 2010) but many undescribed forms continue to be found. The sample material is exceptional in its $\delta^{13} \mathrm{C}$ chemostratigraphic correlation to outcrop sections with macrobiostratigraphic age control (see Jarvis et al., 2006). This paper describes five new species and one new subspecies from the British Geological Survey (BGS) Banterwick Barn (Berkshire; northern AngloParis Basin) and BGS Trunch borehole (Norfolk, southern North Sea Basin; Fig. 1).

\section{Materials and methods}

The Banterwick Barn borehole (Berkshire; UK national grid reference SU $51347750 ; 51^{\circ} 29^{\prime} 39^{\prime \prime} \mathrm{N}, 1^{\circ} 15^{\prime} 43^{\prime \prime} \mathrm{W}$ ) was cored in 1996 by the BGS as part of a Chalk aquifer study yielding $\sim 97 \mathrm{~m}$ of Upper and Middle Chalk. Jarvis et al. (2006) used $\delta^{13} \mathrm{C}$ isotope stratigraphy to determine an age range of Lower Turonian to Middle Coniacian. Pearce et al. (2003) demonstrated a significant attenuation/unconformity spanning much of the Middle and Upper Turonian. The Trunch borehole (Norfolk; UK national grid reference TG 29333455 ; 52 $51^{\prime} 34^{\prime \prime} \mathrm{N}, 01^{\circ} 24^{\prime} 19^{\prime \prime} \mathrm{E}$ ), was continuously cored in 1975 by the BGS (then the Institute of
Geological Sciences) to sample the Chalk at its most complete development in Britain. The 10 in. $(25.4 \mathrm{~cm})$ diameter core recovered a thick Quaternary cover and $468 \mathrm{~m}$ of Cenomanian-lower Maastrichtian Chalk (Wood et al., 1994), including $246 \mathrm{~m}$ of Campanian strata. The chalk samples from the borehole were taken from composite bags of $10 \mathrm{~cm}$ intervals, no cut round of core was preserved. Palynological processing techniques follow that of Pearce et al. (2003). All slides are lodged at the British Geological Survey, Kingsley Dunham Centre, Keyworth, Nottingham, UK. England Finder (EF) coordinates are provided for type and reference specimens. Please note that the slide label must be placed on the right-hand side.

\section{Systematic descriptions}

Division Dinoflagellata (Bütschli, 1885) Fensome et al., 1993.

Subdivision Dinokaryota Fensome et al., 1993.

Class Dinophyceae Pascher, 1914.

Subclass Peridiniphycidae Fensome et al., 1993.

Order Gonyaulacales Taylor, 1980.

Suborder Ceratiineae Fensome et al., 1993.

Family Ceratiaceae Willey and Hickson, 1909.

Genus Odontochitina Deflandre, 1937. 


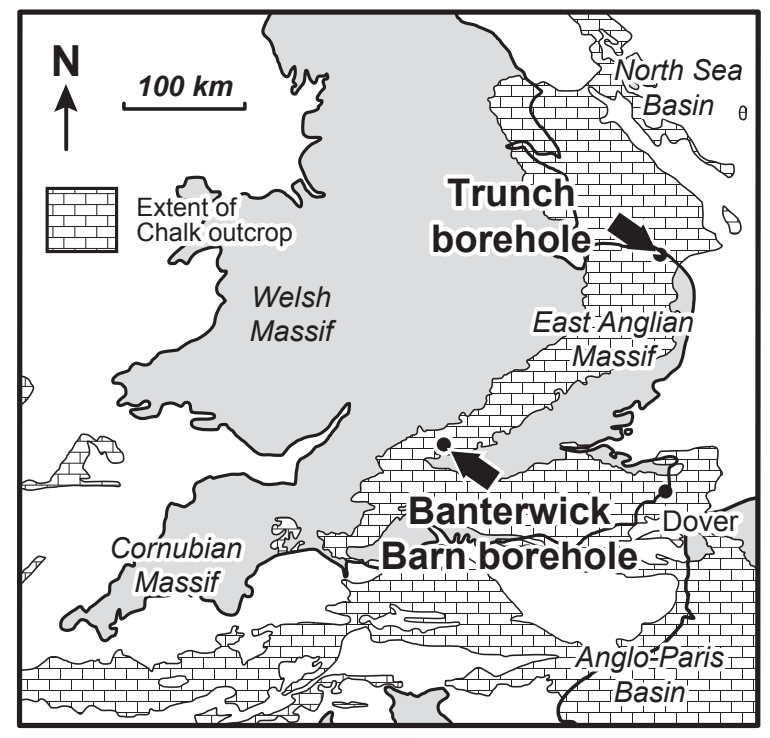

Figure 1. Location map of the BGS Banterwick Barn and Trunch boreholes (modified from Rawson, 1992).

Type. Odontochitina operculata (Wetzel, 1933) Deflandre and Cookson, 1955.

Odontochitina diducta Pearce, 2010 emend. nov.

(Pl. 1, figs. 1-3)

1967 Odontochitina costata Alberti, 1961; Clarke and Verdier: pl. 13, fig. 4 only.

1968 Odontochitina sp. Cookson and Eisenack: 112, pl. 2, fig. D.

1991 Odontochitina operculata (Wetzel, 1933) Deflandre and Cookson, 1955; Heine: pl. 27, fig. 15.

1992 Odontochitina sp. Costa and Davey: pl. 3.13, fig. 5.

1997 Odontochitina operculata (Wetzel, 1933) Deflandre and Cookson, 1955; Roncaglia and Corradini: pl. 2, fig. 5.

Emended diagnosis. A cornucavate to hypocavate species of Odontochitina with a widely divergent antapical and lateral horn separated by an angle equal to or greater than $80^{\circ}$.

Emended description. Large ceratioid, cavate dinoflagellate cyst with one apical, antapical and lateral horn of comparable length. The wall is two-layered, comprising a smooth endophragm and smooth, incompletely and faintly striate or distally perforate (although this may be due to corrosion) periphragm. The periphragm and endophragm are appressed in the precingular region with the lateral and antapical horns being either cornucavate or connected by a hypocavation. The endocyst is sub-spherical, lacking obvious projections into the pericoel. The antapical and lateral horns are separated by an angle of greater than $80^{\circ}$.
The paracingulum may be indicated by faint ridges on the periphragm. The archaeopyle is apical Type (tA) and the operculum is detached.

Remarks. In the original description of $O$. diducta, Pearce (2010:62) described the species as having "a welldeveloped cavation connecting the lateral and antapical horns". However, this feature seems to be gradational to specimens from the same material that are cornucavate, and the diagnosis and description are emended here to account for this fact. The specimens referred to as Odontochitina sp. by Cookson and Eisenack (1968) and Costa and Davey (1992) are thus now considered synonymous with $O$. diducta.

Suborder Gonyaulacineae (autonym).

Family Areoligeraceae Evitt, 1963.

Genus Glaphyrocysta Stover and Evitt, 1978.

Type. Glaphyrocysta retiintexta (Cookson, 1965) Stover and Evitt, 1978.

Glaphyrocysta coniacia sp. nov.

(Pl. 1, figs. 4-11)

2003 Glaphyrocysta sp. A Pearce et al.: pl. 1, fig. 8.

Derivation of name. Named after the Coniacian Stage from which the type material was obtained.

Diagnosis. A species of Glaphyrocysta with a microreticulate endophragm and a weakly fibrous periphragm forming processes of highly variable width, united into linear, arcuate, soleate or annulate complexes that unite distally into wide, perforate, recurved and irregular membranes.

Holotype. MPK 14626, EF coordinates: M40, Pl. 1, figs. 4-5.

Paratypes. Paratype 1, MPK 14627, EF coordinates: K46/1, Pl. 1, fig. 6; paratype 2, MPK 14628, EF coordinates: Q21/2, Pl. 1, fig. 7; paratype 3, MPK 14629, EF coordinates: K19, Pl. 1, fig. 8; paratype 4, MPK 14630, EF coordinates: J11, Pl. 1, fig. 9; paratype 5, MPK 14631, EF coordinates: L22/1, Pl. 1, figs. 10-11.

Type locality and horizon. BGS Banterwick Barn borehole, Berkshire; 1.48-1.55 m, Upper Chalk Formation (Broadstairs Chalk Member), Micraster coranguinum Zone (Middle Coniacian).

Description. Medium to large chorate dinoflagellate cyst with a lenticular, dorso-ventrally compressed, central 

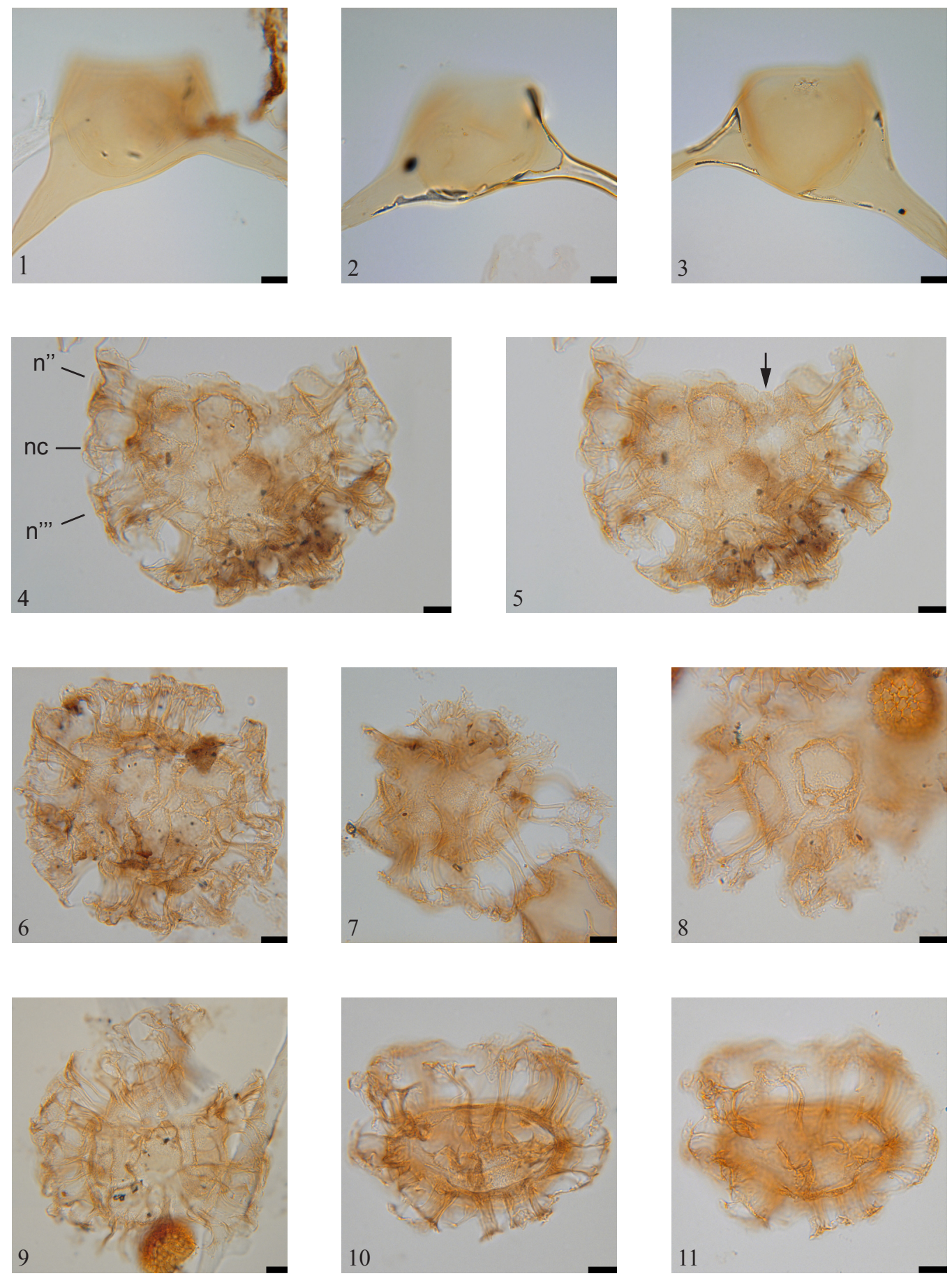

Plate 1. (1-3) Odontochitina diducta Pearce 2010, emend. nov.: (1) showing a very narrow hypopericoel connecting the lateral and antapical horns; (2-3) separate cornucave specimens. (4-5) Glaphyrocysta coniacia sp. nov. (holotype), MPK 14626, EF coordinates: M40: (4) internal (reversed) dorsal view, showing a precingular arcuate complex $-\mathrm{n}^{\prime \prime}$, $\mathrm{nc}$ and $\mathrm{n}^{\prime \prime \prime}$ indicate the precingular, cingular and postcingular series, respectively; (5) external ventral view, with the arrow pointing to the offset sulcal notch. (6) Glaphyrocysta coniacia sp. nov. (paratype 1), MPK 14627, EF coordinates: K46/1: internal (reversed) ventral? view of a complete specimen showing the widely variable process widths. (7) Glaphyrocysta coniacia sp. nov. (paratype 2), MPK 14628, EF coordinates: Q21/2: external view showing the fenestrated distal platforms. (8) Glaphyrocysta coniacia sp. nov. (paratype 3), MPK 14629, EF coordinates: K19: external view showing a dorsal? annulate process. (9) Glaphyrocysta coniacia sp. nov. (paratype 4), MPK 14630, EF coordinates: J11: external dorsal view, showing a partially attached operculum. (10-11) Glaphyrocysta coniacia sp. nov. (paratype 5), MPK 14631, EF coordinates: L22/1: external antapical view showing the dorso-ventral compression. Scale bar represents $10 \mu \mathrm{m}$. 
body and an offset sulcal notch. Two weak antapical bulges may be present. Wall two-layered, comprising a microreticulate endophragm and a slightly fibrous periphragm that separate in the formation of processes. The processes are tabular, apparently solid, and are well developed around the ambitus of the central body, poorly developed on the mid-dorsal area and typically absent on the mid-ventral area. The marginal processes are of variable width but similar length on individual specimens and appear to be clustered into linear groups that are connected distally and may be connected at the base. The mid-dorsal processes may develop into shorter arcuate, soleate or annulate complexes. Distally, the processes widen into perforated platforms that are irregular in shape and typically recurved. The sulcal notch is offset to the left; the cingulum is represented by slender processes at margins of the central body. The archaeopyle is apical, Type tA, typically with a detached operculum.

Dimensions. Holotype, central body $w / l=74 \times 61 \mu \mathrm{m}$, maximum process length $=35 \mu \mathrm{m}$; paratype 1 , central body $w / l=71 \times 62 \mu \mathrm{m}, \quad$ maximum process length $=27 \mu \mathrm{m}$; paratype 2 , central body $w / l=59 \times 53 \mu \mathrm{m}$, maximum process length $=30 \mu \mathrm{m}$; paratype 3 , central body $w / l=60 \times 60 \mu \mathrm{m}, \quad$ maximum process length $=30 \mu \mathrm{m}$; paratype 4 , central body $w / l=70 \times 53 \mu \mathrm{m}$, maximum process length $=25 \mu \mathrm{m}$; paratype 5 , maximum process length $=36 \mu \mathrm{m}$. Range, central body $w / l=46(60) 74 \times 42(55) 64 \mu \mathrm{m}$, maximum process length $=12(29) 36 \mu \mathrm{m}$. Sixteen specimens measured.

Stratigraphic range. Upper Chalk Formation, Broadstairs Chalk Member, Micraster coranguinum Zone (Middle Coniacian), above the White Fall Event in the Banterwick Barn borehole to an unconfirmed upper limit (Fig. 2).

Comparison. The closest species to Glaphyrocysta coniacia sp. nov. are G. exuberans (Deflandre and Cookson, 1955 ex Eaton, 1976) Stover and Evitt, 1978, G. intricata (Eaton, 1971) Stover and Evitt, 1978 and G. texta (Bujak, 1976) Stover and Evitt, 1978. Despite being described from the Palaeogene and therefore being significantly younger, Glaphyrocysta exuberans differs with processes that ramify elaborately halfway along their length, while $G$. intricata and G. texta show much less variability in process width. Glaphyrocysta intricata also differs in having processes that bifurcate distally to a variable length and width.

Family Gonyaulacaceae Lindemann, 1928.

Subfamily Gonyaulacoideae (autonym).

Genus Spiniferites Mantell, 1850.

Type. Spiniferites ramosus (Ehrenberg, 1837) Mantell, 1854.
Spiniferites ramosus subsp. ginakrogiae subsp. nov.

(Pl. 2, figs. 1-6, 7 (left), 8)

Derivation of name. After the Norwegian Gina Krog and oil field (in the Norwegian North Sea) of the same name, where the species has also been recognised.

Diagnosis. A large subspecies of Spiniferites ramosus with a smooth wall, narrow sutural crests and intergonal processes on some of the larger plate boundaries.

Holotype. MPK 14639, EF coordinates: T46, Pl. 2, figs. 1-3.

Paratypes. Paratype 1, MPK 14640, EF coordinates: V19/2, Pl. 2, fig. 4; paratype 2, MPK 14641, EF coordinates: V26/4, Pl. 2, fig. 3.

Type locality and horizon. BGS Trunch borehole, Norfolk; 451.0 m, Upper Chalk (Burnham Chalk Formation), Sternotaxis plana Zone (Upper Turonian).

Description. Large, spiniferate, chorate dinoflagellate cyst with a sub-spherical central body. The wall is twolayered with a thick $(\sim 2 \mu \mathrm{m})$ and smooth endophragm and a thin $(\sim 0.5 \mu \mathrm{m})$ periphragm, the latter of which develops solid processes. Distally trifurcating gonal and bifurcating intergonal processes (on the boundaries between the larger precingular, cingular and postcingular plates) are typically less than one-third the central body diameter, with the furcation occurring from $50 \%$ (on shorter processes) to $25 \%$ (on longer processes) from the distal end. Narrow sutural crests line the processes, often to the distal extremity, occasionally rendering the bi- and trifurcations relatively wide, and define a clear standard gonyaulacacean tabulation. The cingulum is weakly laevorotatory, typically by one cingulum width; the parasulcus lacks clearly developed sutures. The archaeopyle is precingular, Type $\mathrm{P}_{3^{\prime \prime}}$, operculum detached.

Dimensions. Holotype: central body $w / l$ : $74 \times 75 \mu \mathrm{m}$, maximum process length $=22 \mu \mathrm{m}$, paratype 1 : central body $w / l: \quad 71 \times 76 \mu \mathrm{m}, \quad$ maximum process length $=29 \mu \mathrm{m}$, paratype 2 : central body $w / l: 91 \times 80 \mu \mathrm{m}$, maximum process length $=19 \mu \mathrm{m}$. Range central body $w / l=54(69) 91 \mu \mathrm{m} \times 50(69) 84 \mu \mathrm{m}, \quad$ maximum process length, 15(21)30 $\mu \mathrm{m}$. Twenty specimens measured.

Stratigraphic range. Ferriby Chalk Formation, Mantelliceras mantellii Zone (Lower Cenomanian; questionably between the Lower Cenomanian Event I and the Virgatus Beds Event) to the Burnham-Flamborough Chalk Formation (undifferentiated), Gonioteuthis quadrata Zone (Lower Campanian) in the Trunch borehole (Fig. 2). 

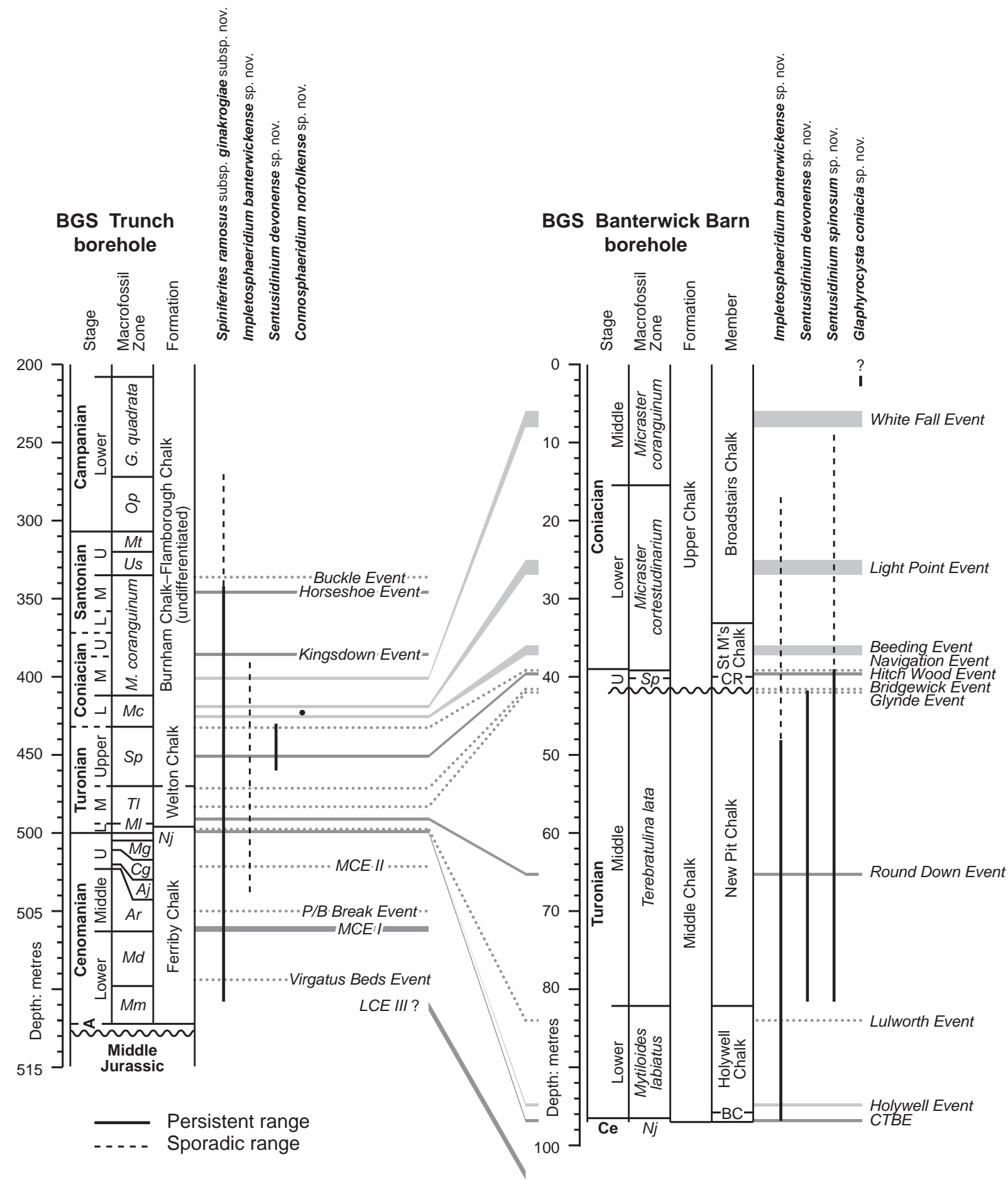

Figure 2. Stratigraphic distribution of the new species from the BGS Banterwick Barn and Trunch boreholes, calibrated by the isotopic events of Jarvis et al. (2006). Abbreviations: A, Albian; Aj, Acanthoceras jukesbrownei; BC, Ballard Cliff Member; Ce, Cenomanian; Cg, Calycoceras guerangeri; CTBE, Cenomanian-Turonian Boundary Event; CR, Chalk Rock; G. quadrata, Gonioteuthis quadrata; L, lower; LCE III, Lower Cenomanian Event III; M, middle; M. coranguinum, Micraster coranguinum; Mc, Micraster cortestudinarium; MCE I, Middle Cenomanian Event I; MCE II, Middle Cenomanian Event II; Md, Mantelliceras dixoni; Mg, Metoicoceras geslinianum; Ml, Mytiloides labiatus; Mm, Mantelliceras mantelli; Mt, Marsupites testudinarius; Nj, Neocardioceras juddii; Op, Offaster pilula; Sp, Sternotaxis plana; St M's Chalk, St Margaret's Chalk; Tl, Terebratulina lata; U, upper; Us, Uintacrinus socialis. Modified from Jarvis et al. (2006). 

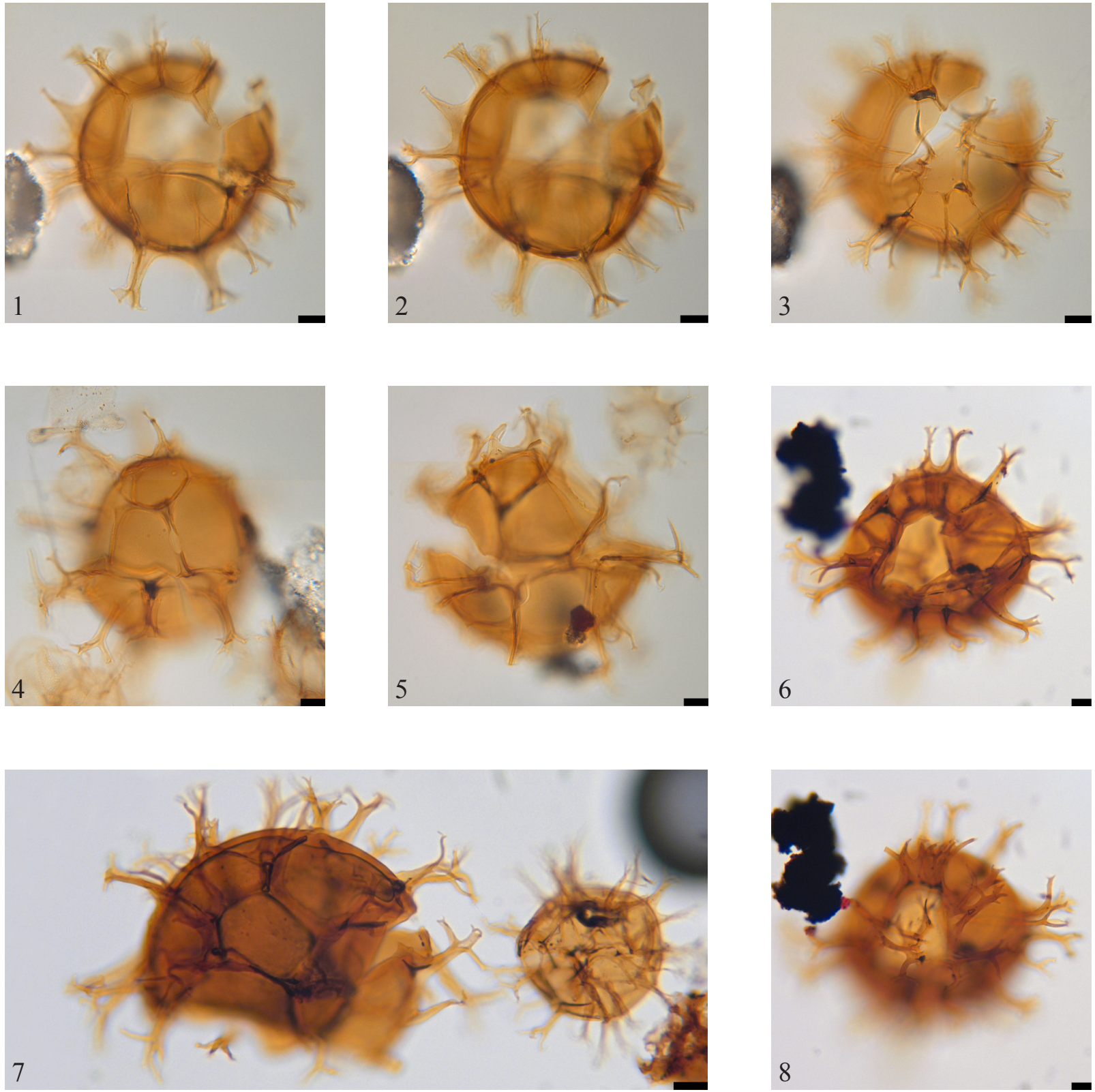

Plate 2. (1-3) Spiniferites ramosus subsp. ginakrogiae subsp. nov. (holotype), MPK 14639, EF coordinates: T46: (1) internal (reversed) dorsal view; (2) ambital view; (3) external ventral view. (4) Spiniferites ramosus subsp. ginakrogiae subsp. nov. (paratype 1), MPK 14640, EF coordinates: V19/2: external (right) lateral view. (5) Spiniferites ramosus subsp. ginakrogiae subsp. nov. (paratype 2), MPK 14641, EF coordinates: V26/4: external (left) lateral view. (6, 8) Spiniferites ramosus subsp. ginakrogiae subsp. nov., specimen from the Gina Krog Field, Norwegian North Sea; (7) Spiniferites ramosus subsp. ginakrogiae subsp. nov. (left) and S. ramosus subsp. ramosus (right), size comparison. Scale bar represents $10 \mu \mathrm{m}$.

Remarks. This species appears to be morphologically intermediate between Spiniferites ramosus subsp. gracilis (by possessing intergonal processes) and Spiniferites porosus (in size). The central body diameter of Spiniferites porosus ranges from 66 to $69 \mu \mathrm{m}$ (the holotype is $66 \times 75 \mu \mathrm{m}$ ), with process lengths ranging from 17 to $36 \mu \mathrm{m}$ (holotype 17$23 \mu \mathrm{m})$ long.
Comparison. Differs from other subspecies of Spiniferites ramosus by its conspicuously large size.

Subfamily Leptodinioideae Fensome et al., 1993.

Genus Conosphaeridium Cookson and Eisenack, 1969. 

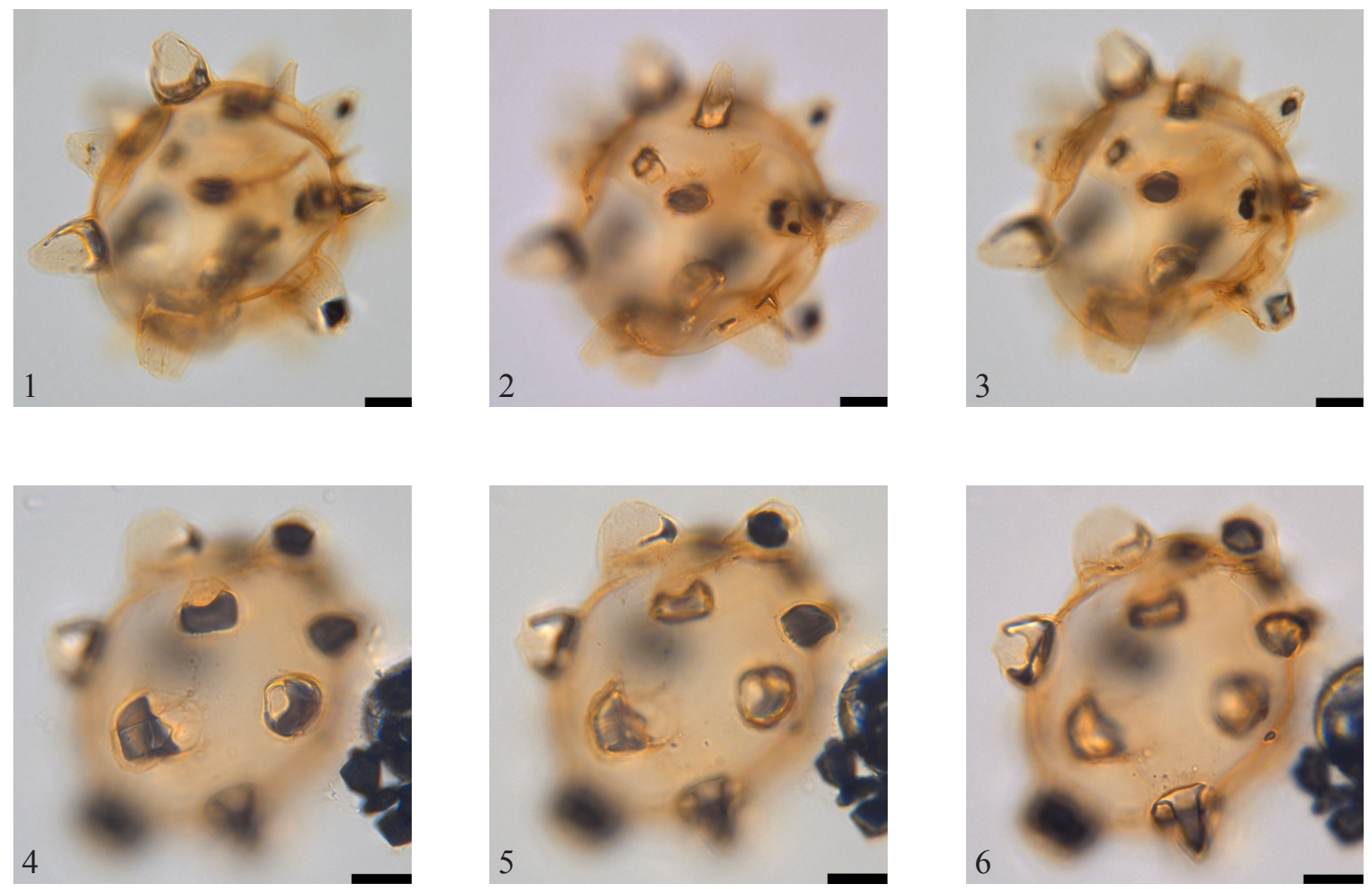

Plate 3. (1-3) Conosphaeridium norfolkense sp. nov. (holotype), MPK 14624, EF coordinates: K37/1: internal (reversed) view of the precingular archaeopyle; precise orientation not determined. (4-6) Conosphaeridium norfolkense sp. nov. (paratype), MPK 14625, EF coordinates: V26/1: external view; precise orientation not determined. Scale bar represents $10 \mu \mathrm{m}$.

Type. Conosphaeridium striatoconum (Deflandre and Cookson, 1955) Cookson and Eisenack, 1969.

\section{Conosphaeridium norfolkense sp. nov.}

(Pl. 3, figs. 1-6)

1976 Conosphaeridium cf. striatoconum of Benson: pl. 1, figs. 4-5.

Derivation of name. Named after the English county of Norfolk, from where the type material was obtained.

Diagnosis. A species of Conosphaeridium with a smooth to only very weakly striate periphragm.

Holotype. MPK 14624, EF coordinates: K37/1, Pl. 3, figs. 1-3.

Paratype. MPK 14625, EF coordinates: V26/1, Pl. 3, figs. 4-6.

Type locality and horizon. BGS Trunch borehole, Norfolk; $423.0 \mathrm{~m}$, Upper Chalk (Burnham Chalk Formation), Micraster cortestudinarium Zone (Lower Coniacian).
Description. Medium-sized proximochorate dinoflagellate with a globular sub-spherical central body. The wall is two-layered, comprised of a thin, smooth endophragm and smooth to very weakly striate periphragm that forms hollow intratabular processes. The processes are relatively squat, rounded-lagenate and typically open distally. The archaeopyle is precingular, Type $\mathrm{P}_{3^{\prime \prime}}$, the operculum may be attached, but more usually detached.

Dimensions. Holotype, central body diameter $=60 \mu \mathrm{m}$, maximum processes length $=17 \mu \mathrm{m}$. Paratype, central body diameter $=51 \mu \mathrm{m}$, maximum processes length $=12 \mu \mathrm{m}$. Range, central body diameter $=44(54) 65 \mu \mathrm{m}$, maximum processes length $=8(12) 17 \mu \mathrm{m}$. Six specimens measured.

Stratigraphic range. Only observed from the sample containing the holotype, between the Beeding and Light Point events (Fig. 2).

Comparison. Both Conosphaeridium abbreviatum Wilson, 1984 and C. striatoconum (Deflandre and Cookson, 1955) Cookson and Eisenack, 1969 differ by possessing strong ribs on the processes; the former also has a much larger central body size (holotype body diameter $95 \times 81 \mu \mathrm{m}$ ). Brideaux 
and McIntyre (1975, pl. 7, figs. 17-18) figured a specimen as Conosphaeridium sp. A from the Middle Albian of northern Canada that is similar to $C$. norfolkense in possessing a very weakly striate periphragm, but which differs in the shape of the processes that are tubular and narrow distally with a truncated distal margin. The specimen figured as Conosphaeridium cf. striatoconus by Benson (1976) from the undifferentiated Upper Cretaceous of Maryland, USA, is considered here synonymous with $C$. norfolkense sp. nov.

\section{Subfamily uncertain}

Genus Sentusidinium Sarjeant and Stover, 1978.

Type. Sentusidinium rioultii (Sarjeant, 1968) Sarjeant and Stover, 1978.

Remarks. As stated by Wood et al. (2016) in their emendation of the genus, the operculum of Sentusidinium is normally detached (implying that attached operculae are permitted), and deep accessory archaeopyle sutures are typically present.

\section{Sentusidinium devonense sp. nov.}

(Pl. 4, figs. 1-12)

1987 Sentusidinium sp. B in Tocher and Jarvis: pl. 9.3, figs. 7-9.

1995 Canningia sp. B FitzPatrick: fig. 9n.

Derivation of name. From the English county of Devon, from where the species was originally recorded.

Diagnosis. A species of Sentusidinium with an even covering of short, flexuous and acuminate spines.

Holotype. MPK 14634, EF coordinates: O17, Pl. 4, figs. 1-3.

Paratypes. Paratype 1, MPK 14635, EF coordinates: F37/3, Pl. 4, figs. 4-6; paratype 2, MPK 14636, EF coordinates: D50/4, Pl. 4, figs. 7-9; paratype 3, MPK 14637, EF coordinates: L16, Pl. 4, figs. 10-12.

Type locality and horizon. BGS Banterwick Barn borehole, Berkshire; 48.06-48.09 m, Middle Chalk Formation, New Pit Chalk Member, Terebratulina lata Zone (Middle Coniacian).

Description. A medium-sized proximate dinoflagellate cyst with a sub-rounded body. The wall is composed of a finely granular autophragm that possesses short $(\sim 2 \mu \mathrm{m})$, evenly distributed and apparently solid, simple flexuous spines with acuminate tips. No expression of the cingulum or sulcus is present. The archaeopyle is apical, Type tA, with a zig-zag margin and clear accessory sutures. The operculum may be attached but more usually detached.
Dimensions. Holotype, central body $w / l$ (excluding operculum) $=66 \times 43 \mu \mathrm{m}$, maximum process length $2 \mu \mathrm{m}$; paratype 1 , central body $w / l$ (excluding operculum) $=65 \times 48 \mu \mathrm{m}$, maximum process length $2 \mu \mathrm{m}$; paratype 2 , central body $w / l=68 \times 50 \mu \mathrm{m}, \quad$ maximum process length $2 \mu \mathrm{m}$; paratype 3 , central body $w / l=60 \times 50 \mu \mathrm{m}$, maximum process length $3 \mu \mathrm{m}$. Range, central body $w / l$ (excluding operculum $)=40(61) 76 \times 40(48) 60 \mu \mathrm{m}$, maximum process length $=2(2) 3 \mu \mathrm{m}$. Seventeen specimens measured.

Stratigraphic range. Middle Chalk Formation, Holywell Chalk Member, Mytiloides labiatus/Terebratulina lata boundary (Middle Turonian; between the Lulworth and Round Down events in the Banterwick Barn borehole) to the Burnham-Flamborough Chalk Formation (undifferentiated), Micraster cortestudinarium Zone (Lower Coniacian; between the Navigation and Beeding events in the Trunch borehole; Fig. 2).

Remarks. FitzPatrick (1995) described the informal species Canningia sp. B from the Turonian of Southern England. She considered the generic attribution based on the subspherical outline, non-tabular spinose ornament and apical archaeopyle; however, she also mentioned the lack of an offset sulcal notch. These observations suggest that the species is not an areoligeracean, and that it has a greater affinity with Sentusidinium, and it is here considered synonymous with $S$. devonense sp. nov.

Comparison. For such a simple genus of dinoflagellate cyst, there are a number of comparable species, but which all differ in the shape of the central body and/or the morphology of the processes. Sentusidinium aptiense (Burger, 1980a) Burger, 1980b possesses hollow tubular spines and S. capillatum (Davey, 1975) Lentin and Williams, 1981, S. echinatum (Gitmez and Sarjeant, 1972) Sarjeant and Stover, 1978 and S? millepiedii (Jain and Millepied, 1975) Islam, 1993 possesses much more densely distributed ornament. Sentusidinium capitatum (Cookson and Eisenack, 1960) Wood et al., 2016 may possess short spines with acuminate tips but the body is distinctly elongate, while $S$. minus (Jiabo, 1978) He et al. in He et al., 1989 is significantly smaller. Sentusidinium myriatrichum Fensome, 1979 possesses significantly shorter and denser ornament and $S$. perforoconum (Yun Hyesu, 1981) Islam, 1993 has a densely perforate periphragm. Sentusidinium pilosum (Ehrenberg, 1854) Sarjeant and Stover, 1978 has a denser cover of short processes with variable tips that are also variable in $S$. rioultii Sarjeant, 1968, S. sahii (Khanna and Singh, 1981) Wood et al., 2016, S. sparsibarbatum Erkmen and Sarjeant, 1980 and S. villersense (Sarjeant, 1968) Sarjeant and Stover, 1978. Sentusidinium separatum (McIntyre and Brideaux, 1980) Lentin and Williams, 1981 has bifid and branched process tips. 

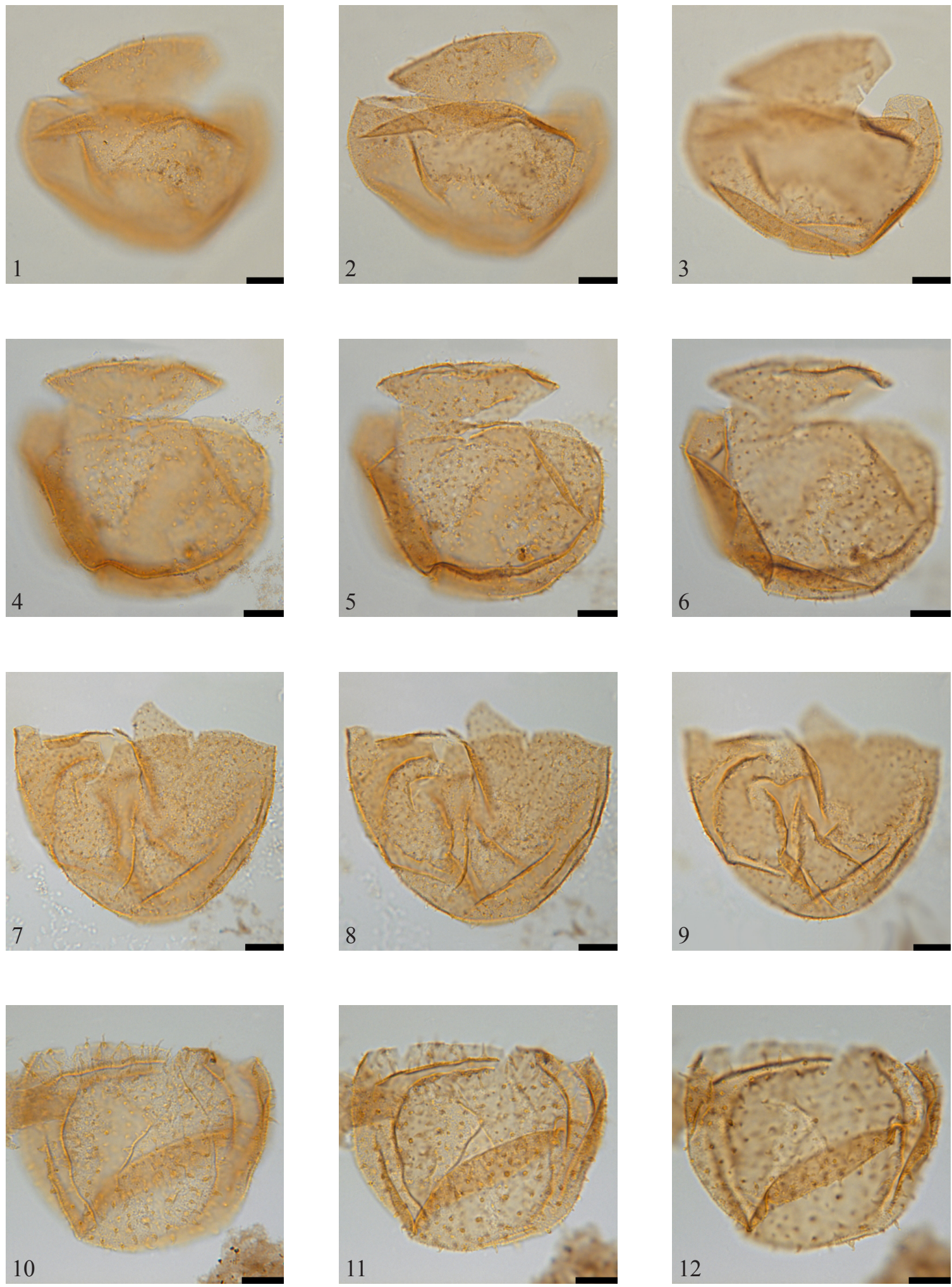

Plate 4. (1-3) Sentusidinium devonense sp. nov. (holotype), MPK 14634, EF coordinates: O17: (1) external view; (3) internal (reversed) view. (4-6) Sentusidinium devonense sp. nov. (paratype 1), MPK 14635, EF coordinates: F37/3: (4) external view; (6) internal (reversed) view. (7-9) Sentusidinium devonense sp. nov. (paratype 2), MPK 14636, EF coordinates: D50/4: (7) external view; (9) internal (reversed) view. (10-12) Sentusidinium devonense sp. nov. (paratype 3), MPK 14637, EF coordinates: L16: (10) external view; (12) internal (reversed) view. Scale bar represents $10 \mu \mathrm{m}$. 
Sentusidinium spinosum sp. nov.

(Pl. 5, figs. 1-6)

Derivation of name. From the Latin spinosum, meaning spiny.

Diagnosis. A species of Sentusidinium with an even covering of relatively long, flexuous and acuminate spines.

Holotype. MPK 14638, EF coordinates: S13/4, Pl. 5, figs. 1-6.

Type locality and horizon. BGS Banterwick Barn borehole, Berkshire; 39.55-39.59 m, Upper Chalk Formation, St. Margaret's Chalk Member, Sternotaxis plana Zone (Middle Turonian).

Description. A medium-sized proximate dinoflagellate cyst with a sub-rounded body. The wall is composed of a micro-reticulate autophragm that possesses relatively long (4-16 $\mu \mathrm{m})$, evenly distributed, hollow spines with simple acuminate tips. No expression of the cingulum or sulcus is present. The archaeopyle is apical, Type tA, with a zig-zag margin and clear accessory sutures. The operculum may be attached but more usually detached.

Dimensions. Holotype, central body $w / l=61 \times 48 \mu \mathrm{m}$, maximum process length $=11 \mu \mathrm{m}$. Range, central body $w / l=46(56) 72 \times 30(46) 56 \mu \mathrm{m}$, maximum processes length $=4(6) 16 \mu \mathrm{m}$. Twenty specimens measured.

Stratigraphic range. Middle Chalk Formation, Holywell Chalk Member, Mytiloides labiatus/Terebratulina lata boundary (Middle Turonian; between the Lulworth and Round Down events) to the Upper Chalk Formation, Broadstairs Chalk Member, Micraster coranguinum Zone (Middle Coniacian; below the White Fall Event) in the Banterwick Barn borehole (Fig. 2).

Comparison. Sentusidinium aptiense (Burger, 1980a) Burger, 1980b also possesses hollow spines but which differ from $S$. spinosum sp. nov. in their relatively shorter length of 3-4 $\mu \mathrm{m}$. These species also have mutually exclusive ranges, being Callovian to Aptian for S. aptiense (Wood et al., 2015) and Turonian for S. spinosum sp. nov. Sentusidinium densicomatum (Maier, 1959) Sarjeant, 1983 differs in possessing more densely distributed hair-like projections. The processes are also much more numerous on $S$. pilosum (Ehrenberg, 1854) Sarjeant and Stover, 1978 and which also have variable tips. Spine length is comparable on $S$. sahii (Khanna and Singh, 1981) Wood et al., 2016 and S. seperatum (McIntyre and Brideaux, 1980) Lentin and Williams, 1981 but which also have variable tips in the former and bifid and branched tips in the latter.

\section{Suborder uncertain}

Family uncertain

Genus Impletosphaeridium Morgenroth, 1966.

Type. Impletosphaeridium transfodum Morgenroth, 1966.

Impletosphaeridium banterwickense sp. nov.

(Pl. 5, figs. 7-12)

Derivation of name. Named after Banterwick Barn, the borehole from where the species is described.

Diagnosis. A species of Impletosphaeridium possessing spines that terminate distally into a simple bifurcation with endings of equal length.

Holotype. MPK 14632, EF coordinates: Q35/2, Pl. 5, figs. 7-9.

Paratype. MPK 14633, EF coordinates: K6/3, Pl. 5, figs. 10-12.

Type locality and horizon. BGS Banterwick Barn borehole, Berkshire; 79.51-79.53 m, Middle Chalk Formation, New Pit Chalk Member, Terebratulina lata Zone (Middle Turonian).

Description. A small chorate dinoflagellate cyst with a sub-rounded body. The wall is composed of a finely granular autophragm from which arises evenly distributed, nontabular solid spines, which terminate in a short bifurcation. No expression of the cingulum or sulcus is present. The archaeopyle is apical, Type tA, with a zig-zag margin and accessory sutures. The operculum may be attached but more usually detached.

Dimensions. Holotype, central body $w / l=46 \times 39 \mu \mathrm{m}$, maximum process length $=12 \mu \mathrm{m}$. Paratype, central body $w / l=46 \times 39 \mu \mathrm{m}, \quad$ maximum process length $=14 \mu \mathrm{m}$. Range, central body $w / l=35(41) 47 \times 29(36) 43 \mu \mathrm{m}$, maximum process length $=10(13) 16 \mu \mathrm{m}$. Twenty specimens measured.

Stratigraphic range. Middle Chalk Formation, Ballard Cliff Member (uppermost Cenomanian; upper CenomanianTuronian Boundary Event) in the Banterwick Barn borehole to the Burnham-Flamborough Chalk Formation (undifferentiated), Micraster coranguinum Zone (Middle Coniacian; between the White Fall and Kingsdown events) in the Trunch borehole (Fig. 2).

Comparison. Impletosphaeridium furcillatum (Prössl, 1990 ex Prössl, 1992) Williams et al., 1998 differs in possessing thicker bifurcate to multifurate processes, while 

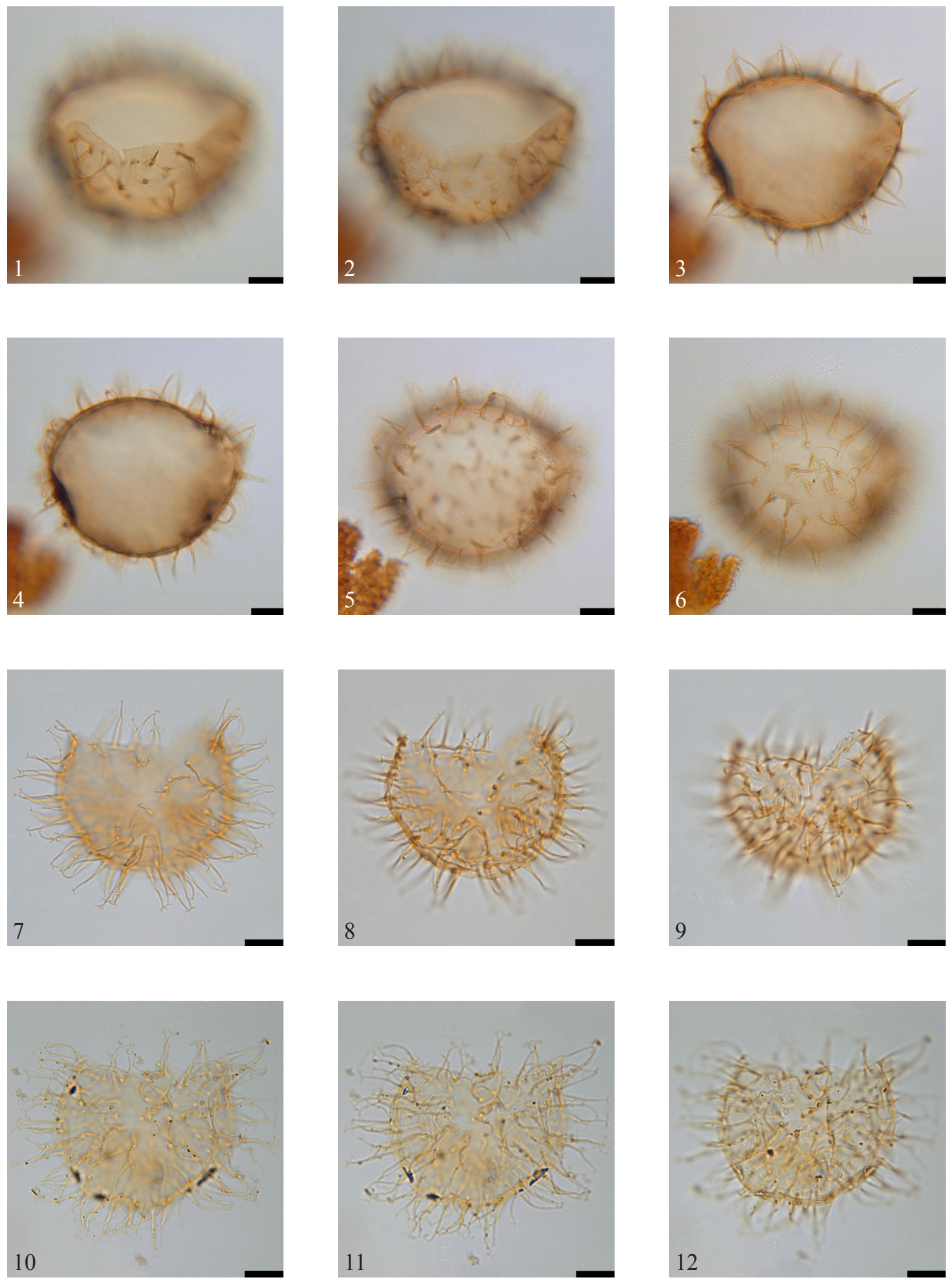

Plate 5. (1-6) Sentusidinium spinosum sp. nov. (holotype), MPK 14638, EF coordinates: S13/4: (1) internal (reversed) view, showing the archaeopyle margin; (6) external view of the antapical region. (7-9) Impletosphaeridium banterwickense sp. nov. (holotype), MPK 14632, EF coordinates: Q35/3: (7) external view; (9) internal (reversed) view. (9-12) Impletosphaeridium banterwickense sp. nov. (paratype), MPK 14633, EF coordinates: K6/3: (10) external view; (12) internal (reversed) view. Scale bar represents $10 \mu \mathrm{m}$. 
I. ligospinosum (de Coninck, 1969) Islam, 1983 differs in possessing bifurcations of unequal length. In I. varispinosum (Sarjeant, 1959) Islam, 1993, the spines are more numerous and differ in being occasionally simple but more frequently bifurcate, clavate or "hammer-headed". The only similar species of comparable age is I. williamsii (Boltenhagen, 1977) Islam, 1993; although it possesses acuminate to bifurcate processes, many of the latter style more closely resemble flared process endings than bifurcating spines. Species of Downiesphaeridium differ in possessing hollow (and distally closed) processes, the closest species of which is D. aciculare (Davey, 1969) Islam, 1993, which differs further by possessing wider (although relatively thin), bladelike processes. According to Davey (1969), the processes of Downiesphaeridium aciculare are always pointed distally and occasionally bear small subsidiary spines near their extremities. In I. banterwickense sp. nov., the subsidiary spines occur at the extremity and are significantly longer.

Data availability. All slides are lodged at the British Geological Survey, Kingsley Dunham Centre, Keyworth, Nottingham, UK. England Finder (EF) coordinates are provided for type and reference specimens.

Competing interests. The author declares that he has no conflict of interest.

Acknowledgements. My thanks to the British Geological Survey for access to the Banterwick Barn and Trunch borehole material and to Malcolm Jones (Palynological Laboratory Services) for preparing the Trunch palynological slides. My sincere thanks to reviewers Chris Clowes and Iain Prince and the editor, Francesca Sangiorgi, whose comments much improved an earlier draft of the manuscript. Printing costs were covered by Evolution Applied Limited.

Edited by: Francesca Sangiorgi

Reviewed by: Chris Clowes and Iain Prince

\section{References}

Alberti, G.: Zur Kenntnis mesozoischer und alttertiärer Dinoflagellaten und Hystrichosphaerideen von Nord- und Mitteldeutschland sowie einigen anderen europäischen Gebieten, Paläeontographica, Abteilung A, 116, 1-58, 1961.

Benson, D. G.: Dinoflagellate taxonomy and biostratigraphy at the Cretaceous-Tertiary boundary, Round Bay, Maryland, Tulane Studies in Geology and Paleontology, 12, 169-233, 1976.

Boltenhagen, E.: Microplancton du Crétacé supérieur du Gabon, Cahiers de paléontologie, un-numbered: 1-150, 1977.

Brideaux, W. W. and McIntyre, D. J.: Miospores and microplankton from Aptian-Albian rocks along Horton River, District of
Mackenzie, Geological Survey of Canada, Bulletin, 252, 1-85, 1975.

Bujak, J. P.: An evolutionary series of Late Eocene dinoflagellate cysts from southern England, Mar. Micropaleontol., 1, 101-117, 1976.

Burger, D.: Palynological studies in the Lower Cretaceous of the Surat Basin, Australia. Bureau of Mineral Resources, Geology and Geophysics, Bulletin, 189, 1-106, 1980a.

Burger, D.: Early Cretaceous (Neocomian) microplankton from the Carpentaria Basin, northern Queensland, Alcheringa, 4, 263 279, 1980b.

Bütschli, O.: Erster Band. Protozoa, in: Dr. H.G. Bronn's Klassen und Ordnungen des Thier-Reichs, wissenschaftlich dargestellt in Wort und Bild, C.F. Winter'sche Verlagsbuchhandlung, Leipzig, 865-1088, 1885.

Clarke, R. F. A. and Verdier, J.-P.: An investigation of microplankton assemblages from the Chalk of the Isle of Wight, England, Verhandelingen der Koninklijke Nederlandse Akademie van Wetenschappen, Afdeeling Natuurkunde, Eerste Reeks, 24, 1-96, 1967.

Cookson, I. C.: Cretaceous and Tertiary microplankton from southeastern Australia, Proceedings of the Royal Society of Victoria, 78, 85-93, 1965.

Cookson, I. C. and Eisenack, A.: Upper Mesozoic microplankton from Australia and New Guinea, Palaeontology, 2, 243-261, 1960.

Cookson, I. C. and Eisenack, A.: Microplankton from two samples from Gingin Brook No.4 borehole, Western Australia, Journal of the Royal Society of Western Australia, 51, 110-122, 1968.

Cookson, I. C. and Eisenack, A.: Some microplankton from two bores at Balcatta, Western Australia, Journal of the Royal Society of Western Australia, 52, 3-8, 1969.

Costa, L. I. and Davey, R. J.: Dinoflagellate cysts of the Cretaceous System, in: A Stratigraphic Index of Dinoflagellate Cysts, edited by: Powell, A. J., Special Publication of the British Micropalaeontological Society, London, 99-131, 1992.

Davey, R. J.: Non-calcareous microplankton from the Cenomanian of England, northern France and North America, part I. British Museum (Natural History) Geology, Bulletin, 17, 103180, 1969.

Davey, R. J.: A dinoflagellate cyst assemblage from the Late Cretaceous of Ghana. Proceedings of the 5th West African Colloquium on Micropaleontology, 7, 150-173, 1975.

de Coninck, J.: Dinophyceae et Acritarcha de l'Yprésien du sondage de Kallo, Mémoires de l'Institut royal des sciences naturelles de Belgique, 161, 1-67, 1969.

Deflandre, G.: Microfossiles des silex crétacés. Deuxième partie. Flagellés incertae sedis. Hystrichosphaeridés. Sarcodinés. Organismes divers, Ann. Paleontol., 26, 51-103, 1937.

Deflandre, G. and Cookson, I. C.: Fossil microplankton from Australian Late Mesozoic and Tertiary sediments, Aust. J. Mar. Fres. Res., 6, 242-313, 1955.

Eaton, G. L.: A morphogenetic series of dinoflagellate cysts from the Bracklesham Beds of the Isle of Wight, Hampshire, England, in: Proceedings of the 2nd Planktonic Conference, edited by: Farinacci, A., Rome, 1970, 355-379, 1971.

Eaton, G. L.: Dinoflagellate cysts from the Bracklesham Beds (Eocene) of the Isle of Wight, southern England, British Museum (Natural History) Geology, Bulletin, 26, 227-332, 1976. 
Ehrenberg, C. G.: Über das Massenverhältniss der jetzt lebenden Kiesel-Infusorien und über ein neues Infusorien-Conglomerat als Polirschiefer von Jastraba in Ungarn. Abhandlungen der Königlichen Akademie der Wissenschaften zu Berlin, aus dem Jahre 1836, Physikalische Klasse, 109-135, 1837.

Ehrenberg, C. G.: Mikrogeologie: das Erden- und Felsenschaffende Wirken des unsichtbaren kleinen selbständigen Lebens auf der Erde, Leopold Voss, Leipzig, 374+31+88 pp., 1854.

Erkmen, U. and Sarjeant, W. A. S.: Dinoflagellate cysts, acritarchs and tasmanitids from the uppermost Callovian of England and Scotland: with a reconsideration of the "Xanthidium pilosum" problem, Geobios, Lyon, 13, 45-99, 1980.

Evitt, W. R.: A discussion and proposals concerning fossil dinoflagellates, hystrichospheres, and acritarchs, II. National Academy of Sciences, Washington, Proceedings, 49, 298-302, 1963.

Fensome, R. A.: Dinoflagellate cysts and acritarchs from the Middle and Upper Jurassic of Jameson Land, east Greenland, Grønlands Geologiske Undersøgelse, Bulletin, 132, 1-98, 1979.

Fensome, R. A., Taylor, F. J. R., Norris, G., Sarjeant, W. A. S., Wharton, D. I., and Williams, G. L.: A Classification of Living and Fossil Dinoflagellates, Micropaleontological Press, Special Publication, 7, 351 pp., 1993.

FitzPatrick, M. E. J.: Dinoflagellate cyst biostratigraphy of the Turonian (Upper Cretaceous) of southern England, Cretaceous Res., 16, 757-791, 1995.

Gitmez, G. U. and Sarjeant, W. A. S.: Dinoflagellate cysts and acritarchs from the Kimmeridgian (Upper Jurassic) of England, Scotland and France. British Museum (Natural History) Geology, Bulletin, 21, 171-257, 1972.

Guerstein, G. R., Fensome, R. A., and Williams, G. L.: A new areoligeracean dinoflagellate from the Miocene of offshore eastern Canada and its evolutionary implications, Paleontology, 41, 2334, 1998.

He, C., Shenzhao, Z., and Guangxing, J.: Early Tertiary microphytoplankton from the Dongpu Region. Series on Stratigraphy and Palaeontology of Oil and Gas Bearing Areas in China. Research Institute of Exploration and Development, Zhongyuan Petroleum Exploration Bureau, Nanjing Institute of Geology and Palaeontology, Academia Sinica - The Petroleum Industry Press, Nanjing, China, 99 pp., 1989.

Heine, C. J.: Late Santonian to Early Maastrichtian dinoflagellate cysts of northeast Texas, in: Stratigraphy and micropalaeontology of the Campanian shelf in northeast Texas, edited by: Thompson, L. B., Heine, C. J., Percival, S. F., and Selznick, M. R., 117-147, Micropalaeontology, Special Publication, 5, 1991.

Islam, M. A.: Dinoflagellate cysts from the Eocene Cliff sections of the Isle of Sheppey, Southeast England, Revue de Micropaléontologie, 25, 231-250, 1983.

Islam, M. A.: Review of the fossil dinoflagellate Cleistosphaeridium, Revista española de micropaleontología, 25, 81-94, 1993.

Jain, K. P. and Millepied, P.: Cretaceous microplankton from Senegal Basin, W. Africa, pt. II. Systematics and biostratigraphy, Geophytology, 5, 126-171, 1975.

Jarvis, I., Gale, A. S., Jenkyns, H. C., and Pearce, M. A.: Secular variation in Late Cretaceous carbon isotopes: a new $\delta^{13} \mathrm{C}$ carbonate reference curve for the Cenomanian-Campanian (99.670.6 Ma), Geol. Mag., 143, 561-608, 2006.
Jiabo: On the Paleogene Dinoflagellates and Acritarchs From the Coastal Region of Bohai. Nanjing Institute of Geology and Palaeontology, Academia Sinica, Nanjing, China, 190 pp., 1978.

Khanna, A. K. and Singh, H. P.: Some new dinoflagellates, spores and pollen grains from the Subathu Formation (Upper Palaeocene-Eocene) of Simla Hills, India, Himal. Geol., 9, 385419, 1981.

Lentin, J. K. and Williams, G. L.: Fossil dinoflagellates: index to genera and species, 1981 Edn., Bedford Institute of Oceanography, Report Series, BI-R-81-12, 345 pp., 1981.

Lindemann, E.: Abteilung Peridineae (Dinoflagellatae), in: Die Natürlichen Pflanzenfamilien nebst ihren Gattungen und wichtigeren Arten insbesondere den Nutzpflanzen, edited by: Engler, A. and Prantl, K., Zweite stark vermehrte und verbesserte Auflage herausgegeben von A. Engler. 2 Band, Wilhelm Engelmann, Leipzig, 3-104, 1928.

Maier, D.: Planktonuntersuchungen in tertiären und quartären marinen Sedimenten, Ein Beitrag zur Systematik, Stratigraphie und Ökologie der Coccolithophorideen, Dinoflagellaten und Hystrichosphaerideen vom Oligozän bis zum Pleistozän, Neues Jahrbuch für Geologie und Paläontologie, Abhandlungen, 107, 278-340, 1959.

Mantell, G. A.: A Pictorial Atlas of Fossil Remains Consisting of Coloured Illustrations Selected from Parkinson's "Organic Remains of a Former World", and Artis's "Antediluvian Phytology”, Henry G. Bohn, London, UK, xii+207 pp., 1850.

Mantell, G. A.: The Medals of Creation; or, First Lessons in Geology and the Study of Organic Remains, 2nd Edn., 930 pp., 6 pl. (in two volumes); Henry G. Bohn, London, UK, 1854.

McIntyre, D. J. and Brideaux, W. W.: Valanginian miospore and microplankton assemblages from the northern Richardson Mountains, District of Mackenzie, Canada, Geological Survey of Canada, Bulletin, 320, 57 pp., 1980.

Morgenroth, P.: Mikrofossilien und Konkretionen des nordwesteuropäischen Untereozäns, Palaeontographica, Abteilung B, 119, 1-53, 1966.

Pascher, A.: Über Flagellaten und Algen, Deutsche Botanische Gesellschaft, Berichte, 32, 136-160, 1914.

Pearce, M. A.: New organic-walled dinoflagellate cysts from the Cenomanian to Maastrichtian of the Trunch borehole, UK, J. Micropalaeontology, 29, 51-72, 2010.

Pearce, M. A., Jarvis, I., Swan, A. R. H., Murphy, A. M., Tocher, B. A., and Edmunds, W. M.: Integrating palynological and geochemical data in a new approach to palaeoecological studies: Upper Cretaceous of the Banterwick Barn Chalk borehole, Berkshire, UK, Mar. Micropaleontol., 47, 271-306, 2003.

Pearce, M. A., Lignum, J. S., and Jarvis, I.: Senoniasphaera turonica (Prössl, 1990 ex Prössl, 1992) comb. nov., senior synonym of Senoniasphaera rotundata alveolata Pearce et al., 2003: an important dinocyst marker for the Lower Turonian chalk of NW Europe, J. Micropalaeontol., 30, 91-93, 2011.

Prince, I. M., Jarvis, I., and Tocher, B. A.: High-resolution dinoflagellate cyst biostratigraphy of the Santonian-Basal Campanian (Upper Cretaceous): New data from Whitecliff, Isle of Wight, England, Rev. Palaeobot. Palyno., 105, 143-169, 1999.

Prince, I. M., Jarvis, I., Pearce, M. A., and Tocher, B. A.: Dinoflagellate cyst biostratigraphy of the Coniacian-Santonian (Upper Cretaceous): new data from the English Chalk, Rev. Palaeobot. Palyno., 150, 59-96, 2008. 
Prössl, K. F.: Dinoflagellaten der Kreide - Unter-Hauterive bis Ober-Turon - im niedersächsischen Becken. Stratigraphie und Fazies in der Kernbohrung Konrad 101 sowie einiger anderer Bohrungen in Nordwestdeutschland, Palaeontographica, Abteilung B, 218, 93-191, 1990.

Prössl, K. F.: Eine Dinoflagellatenpopulation aus dem Eozän von Garoe (Somalia, Ost-Afrika), Giessener Geologische Schriften, 48, 101-123, 1992.

Rawson, P. F.: The Cretaceous, in: Geology of England and Wales, edited by: Duff, P. M. D. and Smith, A. J., Geological Society, London, 355-388, 1992.

Roncaglia, L. and Corradini, D.: Upper Campanian to Maastrichtian dinoflagellate zonation in the northern Apennines, Italy, Newsletters on Stratigraphy, 35, 29-57, 1997.

Sarjeant, W. A. S.: Microplankton from the Cornbrash of Yorkshire, Geol. Mag., 96, 329-346, 1959.

Sarjeant, W. A. S.: Microplankton from the Upper Callovian and Lower Oxfordian of Normandy, Revue de micropaléontologie, 10, 221-242, 1968.

Sarjeant, W. A. S.: A restudy of some dinoflagellate cyst holotypes in the University of Kiel collections. IV. The Oligocene and Miocene holotypes of Dorothea Maier (1959), Meyniana, 35, 85-137, 1983.

Sarjeant, W. A. S. and Stover, L. E.: Cyclonephelium and Tenua: a problem in dinoflagellate cyst taxonomy, Grana, 17, 47-54, 1978.

Stover, L. E. and Evitt, W. R.: Analyses of pre-Pleistocene organicwalled dinoflagellates. Stanford University Publications, Geological Sciences, 15, 300 pp., 1978.

Taylor, F. J. R.: On dinoflagellate evolution, BioSystems, 13, 65$108,1980$.

Tocher, B. A. and Jarvis, I.: Dinoflagellate cysts and stratigraphy of the Turonian (Upper Cretaceous) chalk near Beer, southeast Devon, England, in: Micropalaeontology of Carbonate Environments, edited by: Hart, M. B., Ellis Horwood, British Micropalaeontology Society Series, 138-175, 1987.
Wetzel, O.: Die in organischer Substanz erhaltenen Mikrofossilien des baltischen Kreide-Feuersteins mit einem sedimentpetrographischen und stratigraphischen Anhang, Paläeontographica, Abteilung A, 77, 141-186, 1933.

Willey, A. and Hickson, S. J.: The Protozoa (continued). Section F. - The Mastigophora, in: A Treatise on Zoology. Part 1. Introduction and Protozoa, edited by: Lankester, R., First Fascicle, 154 192, Adam and Charles Black, London (reprinted by A. Asher, Amsterdam, 1964), 1909.

Williams, G. L., Lentin, J. K., and Fensome, R. A.: The Lentin and Williams Index of fossil dinoflagellates 1998 edition. American Association of Stratigraphic Palynologists, Contributions Series, 34, 817 pp., 1998.

Wilson, G. J.: Some new dinoflagellate species from the New Zealand Haumurian and Piripauan stages (SantonianMaastrichtian, Late Cretaceous), New Zeal. J. Bot., 22, 549-556, 1984.

Wood, C. J., Morter, A. A., and Gallois, R. W.: Appendix 1. Upper Cretaceous stratigraphy of the Trunch borehole. TG23SE8, in: Geology of the Country around Great Yarmouth, edited by: Arthurton, R. S., Booth, S. J., Morigi, A. N., Abbott, M. A. W., and Wood, C. J., Memoir for 1:50,000 Sheet 162 (England and Wales) with an Appendix on the Trunch Borehole by Wood and Morter, HMSO, London, 105-110, 1994.

Wood, S. E. L., Riding, J. B., Fensome, R. A., and Williams, G. L.: A review of the Sentusidinium complex of dinoflagellate cysts, Rev. Palaeobot. Palynol., 234, 61-93, 2016.

Yun, H. S.: Dinoflagellaten aus der Oberkreide (Santon) von Westfalen, Palaeontographica, Abteilung B, 177, 1-89, 1981. 